\title{
A Comparative Analysis on the Effects of Formal and Distance Education Students' Course Attendance Upon Exam Success
}

\author{
Recep ÖZ ${ }^{1} \&$ Murat Tolga KAYALAR ${ }^{1}$ \\ ${ }^{1}$ Department of Computer Education and Instructional Technology, Faculty of Education, Erzincan Binali \\ Yildirim University, Erzincan, Turkey \\ Correspondence: Recep ÖZ, Department of Computer Education and Instructional Technology, Faculty of \\ Education, Erzincan Binali Yildirim University, Erzincan, Turkey. E-mail: recepoz@erzincan.edu.tr
}

\author{
Received: March 14, 2021 Accepted: April 17, 2021 Online Published: April 30, 2021 \\ doi:10.5539/jel.v10n3p122 URL: https://doi.org/10.5539/jel.v10n3p122
}

\begin{abstract}
The purpose of this study was to analyze the effect of associate degree formal and distance education students course attendance upon their course achievement. The data were obtained from the institutional records of 516 students who registered in formal education programs and 510 students who registered in distance education programs of a vocational school affiliated to a state university in Eastern Anatolian Region of Turkey. It was noticed that course attendance of formal education students was higher than those who registered in the distance education programs; on the other hand, formal education students were more successful rather than distance education students in terms of midterm, final exam and grade point average. It was determined that course attendance was a significant predictor of midterm, final exam and grade point average, and the achievement scores increased as the course attendance increased, as well. Taking measures to encourage students' attendance in courses in distance education programs and optimizing access and technical infrastructure could positively contribute upon this issue.
\end{abstract}

Keywords: distance education, formal education, academic achievement, course attendance

\section{Introduction}

Education, in the most general sense, is the process of raising individuals according to their specific goals. The personality of individuals undergoing this process changes. This differentiation appears through the knowledge, skills, attitudes and values acquired in the instructional process. Schools have recently been the most important part of the instructional process. Education is not only in schools. Education-school interaction in daily life reminds of school when spoken of education. In fact, there are institutions providing short-term training for preparing the youth and adults for a profession and facilitating their adaptation into life outside the school. As known, formal education is defined as instructional implementations carried out regularly for individuals at a certain age group under the roof of a school with instructional programs prepared according to the goals of National Education (Taymaz, 1978). Within this framework, pre-school education, primary education, secondary education and higher education are the institutions that create formal education system. Formal education is carried on within the framework of a certain curriculum and actualized through instruction. The evaluation process is at certain stages and end of this controlled process. The formal education is regulated in accordance with the laws of pre-school, primary education, secondary education and higher education institutions and includes certain grades within itself. Distance education is the most modern form of education that provides individualized education opportunity independent of time and place and has now been carried out through communication technologies and especially the internet. According to the definition of Clark and Mayer (2003, p. 13), distance education is actualized on computers via CD-ROM, Internet and intranet and has the following features: It has content that enables to reach learning goals. It uses instructional methods that enables learning. It uses different media tools to convey content and method to the students. It produces new knowledge and skills in order to achieve individual learning goals or increase institutional performance.

Distance education is a philosophy of instruction that establishes interaction between students, instructors and materials in different environments and enables to benefit from technology of the age. Distance education provides students the opportunity of completing and repeating the missing knowledge at different times in accordance with the pace of learning (Bolliger \& Wasilik, 2009; Gregory \& Lodge, 2015; Shih, Muñoz, \& 
Sánchez, 2006). Distance education in many developed or developing countries has been carried out to reduce the workload of lecturers in universities (Uşun, 2006, p. 19), to offer better opportunities to students, to decrease costs (Baggaley, 2008; Hall \& Knox, 2009; İşman, 2011, p. 315), to increase the quality of education (Shih, Muñoz, \& Sánchez, 2006) and to increase the prestige of the university (Bolliger \& Wasilik, 2009; Menchaca \& Bekele, 2008). Along with the increase in the number of students in higher education, the insufficient number of classrooms and academic staff lecturing the courses compulsory to be taken in departments necessitates distance education in formal education (Baggaley, 2008; Gök, 2015; Uşun, 2006, p. 268). Maintaining distance education in formal education enriches learning processes (Uşun, 2006, p. 20). Distance education has certain advantages when compared to face-to-face education. Some of these are its being more flexible (in terms of learning pace) and easy to access (Gök, 2015), lowering costs for implementing institution (Bakioğlu \& Can, 2014, p. 28), and increasing academic achievement (Olson \& Wisher, 2002). Distance education has also some disadvantages. The leading of these are the lack of social interaction, lack of individual interaction, and the impossibility of accessing the instructor (Tryon \& Bishop, 2009; Uşun, 2006, p. 20; İşman, 2011, p. 745).

It is possible to see the first examples of distance education in Skinner's Programmed Instruction method. Programmed Instruction is a teaching technique suggested on the basis of reinforcement principles of the famous psychologist Skinner. Programmed Instruction basically offers two remarkable innovations such as individualization of teaching and minimization of error (Demirel, 2000). According to Hizal (1982), the content is grouped under programmed items according to a logical order and offered to students in a programmed instructional method including three basic elements as program, tools and student. The question asked about the content is either answered by the student or one of the given answers is chosen. The students cannot progress to the next programmed item without answering the questions and can progress according to their own learning pace after giving information about the answer (Bayraktar, 1988).

Subsequently, we see that Programmed Instruction implementations have also been improved with the development of computer technologies. The devices used to present programmed instruction materials are called teaching machines. The basic element of teaching machines is the program. The subject to be taught to the student in the program is analyzed in small units considering the principle of progressivity (ordering previous knowledge in a way supporting the subsequent knowledge). Instructions are given on what students will do to learn each unit. The level of learning students have acquired after completing each learning unit is tested. The following learning unit is proceeded comparing the students' answers with the correct answers reinforcing if the students answer correctly. If answered incorrectly, new instructions are given to the students to correct the mistakes, and this continues until the learning unit is fully learned (Senemoğlu, 1997).

Formal education is also defined as the education individuals have at schools or similar institutions before starting their life or profession. Organizing for certain age groups, including steps that are prerequisites for each other (preschool education, primary education, secondary education, higher education), necessity of certain steps for all individuals (primary education), issuing diplomas for those who are successful at the end of the process, and necessity of attendance are considered as its main features.

Distance education was initiated using the method of correspondence, with the idea of delivering learning to more people freeing it from time and space constraints. The foundations of distance education with correspondence in Turkey was laid in 1927, and distance education was started in Banking and Trade Law program of Ankara University, Faculty of Law in 1950s. Since 1980s, distance education has gained momentum in our country, and Anadolu University Open Education Faculty has offered the opportunity of issuing diploma. In 1990s, METU Informatics Institute initiated certificate programs using internet technologies (Kırık, 2014, pp. 83-84). At the onset of developing learning management systems, use of technology in distance education has become extremely important. E-learning including both in-class and out-of-class learning through technology-based media is possible to be expressed as internet-based learning (Musa and Othman, 2012, p. 141; Frimpon, 2012, p. 115).

The concept of distance education including e-learning processes first appeared approximately 300 years ago. E-learning that is also defined as digital and internet-based learning has recently appeared in all areas of education (Liao et al., 2008). E-learning used as an alternative to traditional teaching has become the primary topic of various studies (Douglas et al., 2004). The most important reason for this is that it is suitable for a flexible structure enabling students to access e-learning environments when and where they need (Lee, 2012) Although it has many advantages for students to access learning environments whenever and wherever they want, it also has some disadvantages. Although the positive and negative aspects of e-learning are classified pedagogically in general, the negativity experienced due to the technical infrastructure is at significant levels. It is necessary to consider the relationship of e-learning with time in order to explain the reasons of the advantages 
and disadvantages experienced with the technical structure. E-learning implementations have been used more in developed countries. In developing countries, usage rate is affected from computer skills and social prejudices of individuals.

The accurate planning of learning management systems operating asynchronously and synchronously and including different types of educational materials reduces costs. It is possible to turn e-learning into an advantage with proper planning. E-learning is possible to be customized according to the needs of students, decrease educational costs and increase learning efficiency providing high quality education services (Lee et al., 2009).

Individual interest related to the use of e-learning systems facilitates users' achieving their goals. E-learning ensures the development of individual learning. E-learning systems which offer easy access to information progress according to individual competence and learning opportunities without time and space constraints allows freedom to individuals.

Universities create $65 \%$ of the e-learning market, and $65 \%$ of the universities supports mobile learning. The number of individuals benefiting from e-learning programs increases by $218 \%$ every year. Furthermore, e-learning offers environmental benefits. With the open university, $90 \%$ benefit in energy consumption and $85 \%$ in carbon dioxide emission is provided. E-learning has also been used by businesses. $77 \%$ of businesses in America have used e-learning system for their employees. Every $\$ 1$ allocated to e-learning provides a return of $\$ 30$ increasing productivity.

However, not all e-learning projects are successful. Unsuccessful e-learning projects cause both financial and time losses. E-learning projects are a complex mixture of technological, pedagogical and organizational components that require academic acceptance, and more than a good technical infrastructure is required for the projects because the users of the system are social entities.

When the literature was reviewed, it was noticed that there were various studies carried out at national (Abazoğlu \& Umurhan, 2015; Al \& Madran, 2004; Çandarlı \& Yüksel, 2012; Gelişli, 2015; Karabulut \& Correia, 2008; Karadağ et at., 2008; Karal et al., 2011; Keskin \& Kaya, 2020; Odabaş, 2003; Özbay, 2015; Öz \& Yüksel, 2007) and international (Ainoutdinova et al., 2017; Al-Samarraie, 2019; Bansal, 2020; Bao, 2020; Cavalli, 2017; Clark, 2020; Costa et al., 2020; Crawford et al., 2020; Hung \& Wati, 2020; Mirkholikovna, 2020; Moore, 2013; Perraton, 1981; Roopnarinesingh \& Whiteman, 2020; Setiawan, 2020; Stöhr et al., 2020; Willis, 1993; Holmberg, 2005; Taylor, 2001; Ting et al., 2020; Toquero, 2020; Turchynova et al., 2020) levels. In the study carried out by Baturay and Bay (2015), we noticed that although Internet-based distance education has recently started to be implemented in associate, undergraduate and graduate programs in higher education in our country, it has become widespread rapidly. In 2020-2021 academic year, 25 undergraduate programs in 7 universities and associate degree programs in 31 universities were established, and these universities started to provide distance education at postgraduate degree. These programs have been predicted to increase rapidly spreading to different universities in Anatolia in future.

Computer technology has recently developed much and brought innovations. The fact that computer technology also uses the internet network created for the purpose of communication has provided the opportunity of transfering education to people far away (İ̧man, 2011).

Attendance indicated the number of weeks students attend courses during one semester in 2018-2019 academic year spring semester. Courses attendance indicated to what extent students attended not to a single course, but all courses in associate degree program in 2018-2019 academic year spring semester. Whereas the students' course attendance was determined by the responsible instructor through taking the signatures of students in the formal education program, the record of the student attending in the course in distance education was recorded by the system.

Academic achievement indicated general weighted grade point average of the student. The cumulative grade point average was calculated multiplying the credits of all the courses taken by the student with the coefficient corresponding to the final grade and adding these values and dividing by the total credits.

Whereas the contribution of the midterm exam to the course achievement grade in formal education was $40 \%$, this rate was $20 \%$ in distance education programs. On the other hand, whereas the contribution of the final exam and makeup exam scores to the course achievement was $60 \%$ in formal education, it was $80 \%$ in distance education programs.

The purpose of the study was to analyze the effect of course attendance of formal and distance education students at associate degree level upon course achievement. For this purpose, answers to the following research questions were sought. 
1) Determining whether formal education and distance education students' attendance in classes and their midterm and final exam scores and grade point averages differed significantly,

2) Determining whether the course attendance of students registered in formal and distance education programs was a significant predictor of midterm and final exam scores and grade point averages.

\section{Method}

General screening model was used in the research. General screening model was a research approach aiming to describe a past or current situation as it was. The individual or objects subject to the research were tried to be defined in their own conditions and as they were (Karasar, 2012).

\subsection{Study Group}

The study group included the students registered in Rail Systems Management formal and distance education associate degree programs. Whereas the students registered in distance education program had their courses with internet-based distance education system, the students registered in formal education program had face-to-face courses. Whereas the final exams of the fall and spring semester courses of the students registered in the distance education program were held face-to-face on the University campus, midterm exams were conducted through distance education. The data were obtained from the institutional records of totally 1026 students including 510 from distance education and 516 from formal education.

\subsection{Statistical Procedures}

Independent group t-test was performed to answer the first research question, and simple linear regression analysis was performed to answer the second research question.

\section{Findings}

Independent group t-test was performed to answer the first research question, and simple linear regression analysis was performed to answer the second research question.

Table 1. Independent group t-test results related to course attendance, midterm and final exam scores and grade point averages of the students according to the type of education

\begin{tabular}{|c|c|c|c|c|c|c|c|}
\hline Variable & Type of Education & $\mathrm{N}$ & $\bar{x}$ & Ss & df & $\mathrm{t}$ & $\mathrm{p}$ \\
\hline \multirow{2}{*}{$\begin{array}{l}\text { Number of weeks students } \\
\text { attended courses }\end{array}$} & Formal Education & 516 & 7.97 & 3.74 & 1024 & 10.868 & $.000 *$ \\
\hline & Distance Education & 510 & 5.28 & 4.17 & & & \\
\hline \multirow[t]{2}{*}{ Midterm exam } & Formal Education & 516 & 46.70 & 18.81 & 1024 & 13.941 & $.000 *$ \\
\hline & Distance Education & 510 & 66.83 & 26.80 & & & \\
\hline \multirow[t]{2}{*}{ Final exam } & Formal Education & 516 & 55.47 & 20.61 & 1024 & 10.699 & $.000 *$ \\
\hline & Distance Education & 510 & 40.82 & 23.18 & & & \\
\hline \multirow[t]{2}{*}{ Grade point average } & Formal Education & 516 & 51.96 & 15.41 & 1024 & 5.394 & $.000 *$ \\
\hline & Distance Education & 510 & 46.01 & 19.71 & & & \\
\hline
\end{tabular}

According to the type of education, independent group t-test results related to students' course attendance, midterm and final exam scores and grade point averages were presented in Table 1. It was noticed that the average course attendance in formal education (7.97) was higher than the average course attendance in distance education programs (5.28). A significant difference was determined between the course attendance of formal education students and distance education students $(\mathrm{t}(1024)=10.868, \mathrm{p}<.01)$.

Whereas the midterm score average of formal education students was 46.70 , the midterm score average of distance education students was 66.83. The independent group t-test results indicated that the difference between midterm score averages of formal and distance education students was statistically significant $(\mathrm{t}(1024)=13.941$, $\mathrm{p}<.01)$.

According to the type of education, it was determined that final exam average of formal education students (55.47) was significantly higher rather than final exam averages of distance education students $(40.82)(\mathrm{t}(1024)=$ $10.699, \mathrm{p}<.01)$.

It was also found according to the type of education that grade point averages (51.96) of formal education students was significantly higher rather than grade point averages (46.01) of the distance education students $(\mathrm{t}(1024)=5.394, \mathrm{p}<.01)$. 
Table 2. Simple linear regression analysis results related to predictive power of formal education students' course attendance upon midterm exam score

\begin{tabular}{lllcll}
\hline Model & $\mathrm{B}$ & $\mathrm{S}$. Deviation & Beta & $\mathrm{t}$ & $\mathrm{p}$ \\
\hline (Constant) & 41.655 & 1.939 & & 21.484 & $.000^{*}$ \\
Attendance & .633 & .220 & .126 & 2.873 & $.004^{*}$ \\
$\mathrm{R}=.126$ & $\mathrm{R} 2=.016$ & $\mathrm{~F}(1,514)=8.254, \mathrm{p}<.01$ & & $* \mathrm{p}<.01$ \\
\hline
\end{tabular}

The simple linear regression analysis results related to the predictive power of course attendance of formal education students upon midterm exam scores were presented in Table 2 . The analysis results $(\mathrm{F}(1,514)=8.254$, $\mathrm{p}<.01)$ revealed that established regression model was significant, in general, and the regression equality for predicting the midterm score was in the form of Midterm Exam Score $=41.655+.633$.

Table 3. Simple linear regression analysis results related to the predictive power of distance education students' course attendance upon the midterm exam score

\begin{tabular}{lllcll}
\hline Model & $\mathrm{B}$ & $\mathrm{S}$. Deviation & Beta & $\mathrm{t}$ & $\mathrm{p}$ \\
\hline (Constant) & 60.207 & 1.882 & & 31.998 & $.000^{*}$ \\
Attendance & 1.254 & .280 & .195 & 4.483 & $.000^{*}$ \\
$\mathrm{R}=.195$ & $\mathrm{R}^{2}=.038$ & $\mathrm{~F}_{(1,508)}=20.094, \mathrm{p}<.01$ & & $* \mathrm{p}<.01$ \\
\hline
\end{tabular}

The simple linear regression analysis results related to the predictive power of course attendance of distance education students upon the midterm exam scores were presented in Table 3. One-way ANOVA test results indicated that established regression model was significant, in general $\left(F_{(1,508)}=20.094, p<.01\right)$. The regression equality related to the prediction of the midterm exam score of distance education students was possible to be expressed as Midterm Exam Score $=60.207+1.254$.

Table 4. Simple linear regression analysis results related to the predictive power of formal education students' course attendance upon the final exam score

\begin{tabular}{|c|c|c|c|c|c|}
\hline Model & B & S. Deviation & Beta & $\mathrm{t}$ & $\mathrm{p}$ \\
\hline (Constant) & 36.277 & 1.926 & & 18.832 & $.000^{*}$ \\
\hline Attendance & 2.409 & .219 & .437 & 11.002 & $.000^{*}$ \\
\hline $\mathrm{R}=.437$ & $\mathrm{R}^{2}=.191$ & $\mathrm{~F}_{(1,514)}=121$. & .01 & & ${ }^{*} \mathrm{p}<.01$ \\
\hline
\end{tabular}

The simple linear regression analysis results related to the predictive power of course attendance of formal education students upon the final exam scores were presented in Table 4. The analysis results $\left(\mathrm{F}_{(1,514)}=121.037\right.$, $\mathrm{p}<.01)$ revealed that established regression model was significant, in general, and the regression equality related to prediction of midterm score was in the form of Midterm Exam Score $=36.277+2.409$.

Table 5. Simple linear regression analysis results related to the predictive power of distance education students' course attendance upon the final exam score

\begin{tabular}{llllll}
\hline Model & $\mathrm{B}$ & S. Deviation & Beta & $\mathrm{t}$ & $\mathrm{p}$ \\
\hline (Constant) & 38.096 & 1.652 & & 23.057 & $.000^{*}$ \\
Attendance & .516 & .246 & .093 & 2.102 & $.036^{*}$ \\
$\mathrm{R}=.093$ & $\mathrm{R}^{2}=.009$ & $\mathrm{~F}_{(1,508)}=4.419, \mathrm{p}<.05$ & & & ${ }^{*} \mathrm{p}<.05$ \\
\hline
\end{tabular}

The simple linear regression analysis results related to the predictive power of course attendance of distance education students upon the final exam scores were presented in Table 5. One-way ANOVA test results $\left(\mathrm{F}_{(1,508)}=\right.$ $4.419, \mathrm{p}<.05)$ revealed that established regression model was significant, in general. The regression equality related to prediction of midterm score was in the form of Midterm Exam Score = 38.096 + 516 .

\section{Discussion and Conclusion}

In formal education, the average of course attendance was higher than the average course attendance in distance education programs. Compulsory attendance in formal education, on the other hand, was considered to contributing upon this difference to appear in distance education. Similarly, Özgöl et al. (2017) stated in their 
study carried out with university lecturers and students that students did not regard distance education courses and course attendance was at a low level. This result was in parallel with our study in terms of the low rate of course attendance in distance education program. Conlon (1997) specified in his study that students supported face-to-face education rather than "online" learning. Johnson, Aragon and Shaik (2000) revealed that the students regarded face-to-face education more positively. The finding obtained in this study related to students' expectation on face-to-face education was parallel with our study. In another study, Ak et al. (2018) stated that the students' following live courses was at a low rate.

The average midterm exam score of formal education students was lower than the average midterm exam scores of distance education students. The midterm exams of distance education students were held via online system, and this kept the behaviors possible to affect exam achievement such as cheating or getting help from others out of control.

In the study carried out by Özgöl et al. (2017), some of the students stated that the exams of the courses in distance education were easy, and accordingly, it was easier to pass the exams, and this was positive for them. Furthermore, it was considered that rewatching the courses without time constraints in distance education contributed positively upon academic achievement. In the study carried out by Yağc1 et al. (2011), it was observed that the exams held in digital media contributed significantly upon the achievement of the students.

However, mid-term exams of formal education students were held face to face, and it was possible to say that cheating and such behaviors were in a controllable environment. It was considered that a significant part of the difference between formal and distance education students' midterm achievement score averages was arisen from this.

According to the type of education, the average final exam scores of formal education students was higher than the average final exam scores of distance education students. Although distance education students had higher average midterm exam scores, lower face-to-face final exam averages of formal education students made the reliability of midterm exams questionable.

Course attendance of formal education students and distance education students was a significant predictor of midterm exam scores. However, the rate of course attendance in distance education students was higher in terms of predicting the midterm exam score. When the literature was reviewed, it was noticed that there was a relationship between course attendance and academic achievement (Furrer \& Skinner, 2003; Adiyaman, 2008; Nystrand \& Gamoran, 1991; Uysal, 1999). Çelik et al. (2018) reported a significant positive relationship between academic achievement and cognitive attendance in their studies. Therefore, it was possible to say that as the level of attendance in courses increased, academic achievement increased, as well. In his study analyzing the achievement of students having traditional education and distance education, Durak (2009) found that distance education students had higher achievement in both midterm and final exams rather than the students having traditional education. Kurnaz and Ergün (2019) stated in their study that there was a positive and low-level relationship between having a formal learning style and academic achievement, and active learning was also a predictor of academic achievement. In the literature, there were studies related to the positive effect of e-learning styles upon academic achievement (Hsu, 1994; Ross, Drysdale, \& Schulz, 2001), as well as the findings related to absence of a relationship between learning styles and academic achievement (Omar et al., 2015; Rovai \& Grooms, 2004). As known, the rate of attendance should be kept high in order to increase academic and course achievement. Regardless of the field, the more studies on a subject, the more achievement rates in education and exams were possible to be obtained parallelly, as result.

The course attendance of formal education students and distance education students was a significant predictor of the final exam scores. Unlike the results in midterm exam scores, the rate of attendance in formal education students was higher in predicting the final exam score. Magdalena (2015) found that the students who preferred a learning style based on practical and theoretical experiences and improved their learning depending on real life experiences had higher academic achievement. Moreover, the possibility that the relationship of active learning style with other psychological variables such as motivation for learning and exam anxiety could differ from other learning styles was possible to create a difference in academic achievement of students with active learning styles when compared to the students with other e-learning styles. Therefore, the relationship between e-learning styles and psychological variables such as learning motivation, exam anxiety and metacognitive awareness could be analyzed in further studies.

\section{Recommendations}

It was observed that the academic achievement of those who attended live courses was higher. Therefore, it was recommended that students attendance to live courses should be encouraged. For this purpose, preparing 
presentations and activities possible to encourage attendance in live courses and activating the feedback process could contribute. On the other hand, it was also important to eliminate the lack of devices and internet infrastructure that limited the attendance in live courses.

Types of question that encouraged students to memorize could also negatively affect live attendance. The associability of measurement and assessment activities with the activities in live course process was possible to make live attendance more attractive for students. As Baran (2020) mentioned, precautions to increase the validity of traditional multiple-choice exams in assessments could also have a positive effect upon live attendance.

\section{References}

Abazaoğlu, İ., \& Umurhan, H. (2015). Uzaktan Eğitim ve Öğretim Üyelerini Uzaktan Eğitime Teşvik Eden Faktörler. Journal of Research in Education and Teaching, 4(4), 35.

Adıyaman, Y. Z. (2008). İlköğretim okullarında öğretmenin kullandĭ̆ yöntem, teknik ve etkinliklerin ögrrencinin derse katılımına etkisi ilişskisi. Unpublished Master's dissertation, Yeditepe Üniversitesi, İstanbul.

Ainoutdinova, I. N., Khuziakhmetov, A. N., \& Tregubova, T. M. (2017). Advantages and disadvantages of distance education for university students in Russia. Modern Journal of Language Teaching Methods, $7(9 / 2), 72-86$.

Ak, A., Oral, B., \& Topuz, V. (2018). Marmara Üniversitesi Teknik Bilimler Meslek Yüksekokulu uzaktan öğretim sürecinin değerlendirilmesi. Bilim, Eğitim, Sanat ve Teknoloji Dergisi (BEST Dergi), 2(1), 71-80.

Al, U., \& Madran, O. (2004). Web tabanlı uzaktan eğitim sistemleri: Sahip olması gereken özellikler ve standartlar. Bilgi Dünyast, 5(2), 259-271. https://doi.org/10.15612/BD.2004.491

Al-Samarraie, H. (2019). A Scoping review of videoconferencing systems in higher education: Learning paradigms, opportunities, and challenges. International Review of Research in Open and Distributed Learning, 20(3). https://doi.org/10.19173/irrodl.v20i4.4037

Baggaley, J. (2008). Where did distance education go wrong? Distance Education, 29(1), 39-51. https://doi.org/10.1080/01587910802004837

Bakioğlu, A., \& Can, E. (2014). Uzaktan eğitimde kalite ve akreditasyon. Ankara: Vize Yayıncılık.

Bansal, S. (2020). Impact of the COVID-19 pandemic on education, rise of online teaching learning process \& effects on health of kids. Rise of Online Teaching Learning Process \& Effects on Health of Kids. https://doi.org/10.2139/ssrn.3595971

Bao, W. (2020). COVID - 19 and online teaching in higher education: A case study of Peking University. Human Behavior and Emerging Technologies, 2(2), 113-115. https://doi.org/10.1002/hbe2.191

Baran, H. (2020). Açık ve uzaktan eğitimde ölçme ve değerlendirme. Açıkögretim Uygulamaları ve Araştırmaları Dergisi, 6(1), 28-40.

Baturay, M., \& Bay, Ö. F. (2009). Uzaktan öğretimi tercih eden öğrencilerin demografik özellikleri. Dicle Üniversitesi Ziya Gökalp Eğitim Fakültesi Dergisi, 13, 17-26.

Bayraktar, E. (1988). Bilgisayar Destekli Matematik Ögrretimi. Unpublished doctoral dissertation. A.Ü. Sosyal Bilimler Enstitüsü. Ankara.

Bolliger, D. U., \& Wasilik, O. (2009). Factors influencing faculty satisfaction with online teaching and learning in higher education. Distance Education, 30(1), 103-116. https://doi.org/10.1080/01587910902845949

Candarli, D., \& Yuksel, H. G. (2012). Students' perceptions of video-conferencing in the classrooms in higher education. Procedia-Social and Behavioral Sciences, 47, 357-361. https://doi.org/10.1016/j.sbspro.2012.06.663

Cavalli, M. (2017). Comparison of on-campus and distance learning outcomes in a composite materials course. In ASEE Annual Conference and Exposition, ASEE. https://doi.org/10.18260/1-2--28056

Çelik, S., Toraman, S. Ö., \& Çelik, K. (2018). Öğrenci Başarısının Derse Katılım ve Öğretmen Yakınlığıyla İlişkisi. Kastamonu Eğitim Dergisi, 26(1), 210-217. https://doi.org/10.24106/kefdergi.378129

Clark, J. T. (2020). Distance education (pp. 410-415). Clinical engineering handbook. Academic Press. https://doi.org/10.1016/B978-0-12-813467-2.00063-8

Clark, R. C., \& Mayer, R. E. (2003). E-learning and the Science of Instruction. San Francisco: Pfeiffer 
Conlon, M. (1997). MOOville: The writing project's own "private Idaho". T.H.E. Journal, 24(8), 66-68.

Costa, R. D., Souza, G. F., Castro, T. B., Valentim, R. A., \& Dias, A. P. (2020). Identification of learning styles in distance education through the interaction of the student with a learning management system. IEEE Revista Iberoamericana de Tecnologias del Aprendizaje, 15(3), 148-160. https://doi.org/10.1109/RITA.2020.3008131

Crawford, J., Butler-Henderson, K., Rudolph, J., Malkawi, B., Glowatz, M., Burton, R., ... Lam, S. (2020). COVID-19: 20 countries' higher education intra-period digital pedagogy responses. Journal of Applied Learning \& Teaching, 3(1), 1-20. https://doi.org/10.37074/jalt.2020.3.1.7

Demirel, Ö. (2000). Planlamadan Uygulamaya Öğretme Sanatı. Pegem A Yayıncılık, Ankara.

Douglas, D. E., \& Van der Vyver, G. (2004). Effectiveness of E-learningcourse materials for learning database management systems: Anexperimental investigation. Journal of Computer Information Systems, 44(4), 41.

Durak, G. (2009). Algoritma Konusunda Geliştirilen “Programlama Mantığı Öğretici-P.M. Ö” Yazılımının Öğrenci Başarısına Etkisi. Unpublished Master’s Thesis. Balıkesir: Balıkesir Üniversitesi.

Frimpon, M. F. (2012). A re-structuring of the critical success factors for e-learning deployment. American International Journal of Contemporary Research, 2(3), 115-127.

Furrer, C., \& Skinner, E. (2003). Sense of relatedness as a factor in children's academic engagement and performance. Journal of Educational Psychology, 95, 148-162. https://doi.org/10.1037/0022-0663.95.1.148

Gelişli, Y. (2015). Uzaktan Eğitimde Öğretmen Yetiştirme Uygulamaları: Tarihçe ve Gelişim. Journal of Research in Education and Teaching, 4(3), 34.

Gök, T. (2015). The evaluations of the college students' perceptions on distance education from the point of the technical and educational factors. The Turkish Online Journal of Distance Education, 16(2), 84-93. https://doi.org/10.17718/tojde.19025

Gregory, M. S. J., \& Lodge, J. M. (2015). Academic workload: the silent barrier to the implementation of technology-enhanced learning strategies in higher education. Distance Education, 36(2), 210-230. https://doi.org/10.1080/01587919.2015.1055056

Hall, D., \& Knox, J. (2009). Issues in the education of TESOL teachers by distance education. Distance Education, 30(1), 63-85. https://doi.org/10.1080/01587910902845964

Hızal, A. (1982). Programlı Öğretim Yönteminin Etkenliği. A.Ü.E.B.F. Yayınları, No: 117, Ankara.

Holmberg, B. (2005). Theory and practice of distance education. Routledge. https://doi.org/10.4324/9780203973820

Hsu, T. E. (1994). Effects of learner cognitive styles and metacognitive tools on information acquisition paths and learning in hyperspace environments. 16th National Convention of the Association for Educational communications and Technology Congress. Nashville, TN, February 16-20.

Hung, R., \& Wati, U. A. (2020). Digital home schooling during the pandemic: Possibilities and challenges. Knowledge Cultures, 8(2). https://doi.org/10.22381/KC8220206

İşman, A. (2011). Uzaktan Eğitim. Ankara: Pegem Akademi Yayıncılık.

Johnson, S. D., Aragon, S. R., \& Shaik, N. (2000). Comparative analysis of learner satisfaction and learning outcomes in online and face-to-face learning environments. Journal of Interactive Learning Research, 11(1), $29-49$.

Karabulut, A., \& Correia, A.-P. (2008). Skype, Elluminate, Adobe Connect, and iVisit: A comparison of web-based video conferencing systems for learning and teaching. In K. McFerrin, R. Wagner, R. Carlsen \& D. A. Willis (Eds.), Proceedings of the Society for Information Technology and Teacher Education 2008 (pp. 481-484). Association for the Advancement of Computing in Education.

Karadağ, E., Sağlam, H., \& Baloğlu, N. (2008). Bilgisayar Destekli eğitim [BDE]: ilköğretim okulu yöneticilerinin tutumlarına iliş̧in bir araştırma. Journal of International Social Research, 1(3), 252-266.

Karal, H., Çebi, A., \& Turgut, Y. E. (2011). Perceptions of students who take synchronous courses through video conferencing about distance education. The Turkish Online Journal of Educational Technology, 10(4), 276-293. Retrieved from http://www.tojet.net/articles/v10i4/10428.pdf

Keskin, M., \& Kaya, D. Ö. (2020). COVID-19 Sürecinde öğrencilerin web tabanlı uzaktan eğitime yönelik geri 
bildirimlerinin değerlendirilmesi. Izmir Katip Çelebi Üniversitesi Sağlık Bilimleri Fakültesi Dergisi, 5(2), $59-67$.

Kırık, A. (2014). Uzaktan eğitimin tarihsel gelişimi ve Türkiye'deki durumu. Marmara İletişim Dergisi, 21, 73-94. https://doi.org/10.17829/midr.20142110299

Kurnaz, F. B., \& Ergün, E. (2019). E-öğrenme ortamlarında öğrenme stilleri ve akademik başarı arasındaki ilişkinin incelenmesi. Kuramsal Eğitimbilim Dergisi, 12(2), 532-549. https://doi.org/10.30831/akukeg.407029

Lee, B. C., Yoon, J. O., \& Lee, I. (2009). Learners' acceptance of e-learning in South Korea: Theories and results. Computers \& Education, 53(4), 1320-1329. https://doi.org/10.1016/j.compedu.2009.06.014

Lee, Y. J. (2012). Developing an efficient computational method that estimates the ability of students in a Web-based learning environment. Computers \& Education, 58(1), 579-589. https://doi.org/10.1016/j.compedu.2011.09.008

Liao, H. L., \& Lu, H. P. (2008). The role of experience and innovation characteristics in the adoption and continued use of e-learning websites. Computers \& Education, 51(4), 1405-1416. https://doi.org/10.1016/j.compedu.2007.11.006

Magdalena, S. M. (2015). The relationship of learning styles, learning behavior and learning outcomes at the Romanian students. Procedia-Social and Behavioral Sciences, 180, 1667-1672. https://doi.org/10.1016/j.sbspro.2015.05.062

Menchaca, M. P., \& Bekele, T. A. (2008). Learner and instructor identified success factors in distance education. Distance Education, 29(3), 231-252. https://doi.org/10.1080/01587910802395771

Mirkholikovna, D. K. (2020). Advantages and disadvantages of distance learning. Наука и образование сегодня, 7(54), 70-72.

Moore, M. G. (Ed.). (2013). Handbook of distance education. Routledge. https://doi.org/10.4324/9780203803738

Murphy, M. P. (2020). COVID-19 and emergency eLearning: Consequences of the securitization of higher education for post-pandemic pedagogy. Contemporary Security Policy, 41(3), 492-505. https://doi.org/10.1080/13523260.2020.1761749

Musa, M. A., \& Othman, M. S. (2012). Critical success factor in e-Learning: An examination of technology and student factors. International Journal of Advances in Engineering \& Technology, 3(2), 140.

Nystrand, M., \& Gamoran, A. (1991). Instructional discourse, student engagement, and literature achievement. Research in the Teaching of English, 25, 261-290.

Odabaş, H. (2003). Kurumsal Bilgi Yöntemi. Ayllk Strateji Bilim Dergisi, 10.

Olson, T., \& Wisher, R. A. (2002). The effectiveness of web-based instruction: an initial inquiry. International Review of Research in Open and Distance Learning, 3(2), 1-17. https://doi.org/10.19173/irrodl.v3i2.103

Omar, N., Mohamad, M. M., \& Paimin, A. N. (2015). Dimension of learning styles and students' academic achievement. Procedia-Social and Behavioral Sciences, 204, 172-182. https://doi.org/10.1016/j.sbspro.2015.08.130

Öz, R., \& Yüksel, B. (2007). Uzaktan Eğitim: Makine Mühendisliği Örneği. Erzincan Eğitim Fakültesi Dergisi, $9,2$.

Özbay, Ö. (2015). Dünyada ve Türkiye'de uzaktan eğitimin güncel durumu. Uluslararası Eğitim Bilimleri Dergisi, 5, 376-394. https://doi.org/10.16991/INESJOURNAL.174

Özgöl, M., Sarıkaya, İ., \& Öztürk, M. (2017). Örgün eğitimde uzaktan eğitim uygulamalarına ilişkin öğrenci ve öğretim elemanı değerlendirmeleri. Yükseköğretim ve Bilim Dergisi, 7(2), 294-304. https://doi.org/10.5961/jhes.2017.208

Perraton, H. (1981). A Theory for Distance Education. Prospects: Quarterly Review of Education, 11(1), 13-24. https://doi.org/10.1007/BF02254290

Roopnarinesingh, U., \& Whiteman, A. S. (2020). Tracing the evolution of distance education and its impact on graduate health administration programs. Reports on Global Health Research, 3, 118.

Ross, J. L., Drysdale, M. T., \& Schulz, R. A. (2001). Cognitive Learning Styles and Academic Performance in 
Two Postsecondary Computer Application Courses. Journal of Research on Computing in Education, 33(4), 400-412. https://doi.org/10.1080/08886504.2001.10782324

Rovai, A. P., \& Grooms, L. D. (2004). The relationship of personality-based learning style preferences and learning among online graduate students. Journal of Computer in Higher Education, 16(1), 30-47. https://doi.org/10.1007/BF02960281

Senemoğlu, N. (1997). Gelişim Öğrenme ve Öğretim Kuramdan Uygulamaya. Özsen Matbaası, Ankara.

Setiawan, A. R. (2020). Scientific literacy worksheets for distance learning in the topic of Coronavirus 2019 (COVID-19). Reading Academic Articles. https://doi.org/10.35542/osf.io/swjmk

Shih, P. C., Muñoz, D., \& Sánchez, F. (2006). The effect of previous experience with information and communication technologies on performance in a Web-based learning program. Computers in Human Behavior, 22(6), 962-970. https://doi.org/10.1016/j.chb.2004.03.016

Stöhr, C., Demazière, C., \& Adawi, T. (2020). The polarizing effect of the online flipped classroom. Computers \& Education, 147, 103789. https://doi.org/10.1016/j.compedu.2019.103789

Taylor, J. C. (2001). Fifth generation distance education. Instructional Science and Technology, 4(1), 1-14.

Taymaz, H. (1978). Hizmet içi eğitim üstüne. Ankara: Ankara Üniversitesi Eğitim Fakültesi Yayınları.

Ting, D. S. W., Carin, L., Dzau, V., \& Wong, T. Y. (2020). Digital technology and COVID-19. Nature Medicine, 26(4), 459-461. https://doi.org/10.1038/s41591-020-0824-5

Toquero, C. M. (2020). Challenges and opportunities for higher education amid the COVID-19 pandemic: The Philippine context. Pedagogical Research, 5(4). https://doi.org/10.29333/pr/7947

Tryon, P. J., \& Bishop, M. (2009). Theoretical foundations for enhancing social connectedness in online learning environments. Distance Education, 30(3), 291-315. https://doi.org/10.1080/01587910903236312

Turchynova, G., Hladun, T., Hnoievska, O., Harashchenko, L., Kozak, L., Rudenko, I., \& Tarasova, V. (2020). Entrepreneurship Education of IT-specialists through distance learning technologies. Journal of Entrepreneurship Education, 23(S1). Retrieved from http://enpuir.npu.edu.ua/handle/123456789/28102

Uşun, S. (2006). Uzaktan Ĕgitim. Ankara: Nobel Yayın Dağıtım.

Uysal, F. Ö. (1999). Öğrenme sürecine etkin öğrenci katılımının öğrenme sonuçlarına etkisi. Dokuz Eylül Üniversitesi Buca Ĕ̈itim Fakültesi Dergisi, 11, 358-374.

Willis, B. D. (1993). Distance education: A practical guide. Educational Technology.

Yağc1, M., Ekiz, H., \& Gelbal, S. (2011). 5th International Computer \& Instructional Technologies Symposium (pp. 22-24). Elazı̆ğ.

\section{Copyrights}

Copyright for this article is retained by the author, with first publication rights granted to the journal.

This is an open-access article distributed under the terms and conditions of the Creative Commons Attribution license (http://creativecommons.org/licenses/by/4.0/). 